\title{
Analysis of Shoreline Response due to Wave Energy Incidence Using Equilibrium Beach Profile Concept
}

\author{
Tae-Kon Kim ${ }^{*}$ and Jung-Lyul Lee $\bigoplus^{* *}$ \\ "School of Civil, Architecture and Environmental System Engineering, Sungkyunkwan University, Suwon, Korea \\ "School of Water Resources Engineering, Sungkyunkwan University, Suwon, Korea \\ 평형해빈단면 개념을 이용하여 파랑 에너지 유입에 따른 해안선 변동 해석 \\ 김태곤(1* ${ }^{*}$ 이정렬(** \\ "성균관대학교 건설환경시스템공학과 \\ *성균관대학교 수자원대학원
}

KEY WORDS: Cross-shore sediment transport 횡단표사, Scale factor 축척계수, Median grain size 중앙입경, Beach erosion 해빈침식, Detached breakwater 이안제

\begin{abstract}
Dean's equilibrium beach profile formula was used to investigate the correlation between the static shoreline position and the incident wave energy. The effect of the longshore sediment transport was neglected, and the results showed the reasonable agreement compared with the field observations of Yates et al.(2009), which were conducted for almost 5 years on southern California beaches, USA. The shoreline response varies with the scale factor of Dean's equilibrium beach profile. This implies that the shoreline response could be simply estimated using the sampled grain size without laborious long-term field work. Therefore, the present study results are expected to be practically used for the layout design of submerged or exposed detached breakwaters although the further work is required for performance verification. In addition, after laborous mathematical reviews, the linear relation between incident energy and shoreline response, which was obtained from Yates's field study, yielded a clear mathematical equation showing how the beach slope is related to the grain size.
\end{abstract}

\section{1. 서 론}

최근 연안에서 빈번히 발생하는 침식문제가 사회적 이슈로 크게 대두되고, 이를 예방 또는 방지하고자 하는 모니터링 및 침식저감 기술의 필요성이 증대되고 있다. 그러나 이러한 모니 터링 자료의 분석이나 침식저감 기술의 사전 타당성을 평가할 만한 실질적인 연구 성과는 국내뿐만 아니라 전 세계적으로도 아직 만족할 만한 수준에 도달하지 못하고 있다. 본 연구에서는 파랑 에너지를 제어하여 횡단표사로 인하여 발생하는 침식 문 제를 해결하기 위한 수단으로 검토되는 이안제나 잠제 등의 해 안구조물이 해안선 침식을 얼마나 효과적으로 제어할 수 있는 지를 정량적으로 평가하는 데 유용한 방법론을 제시한다.

연안역에서 모래, 자갈 등 퇴적물이 쌓여 있는 곳을 해빈이라 고 하며, 해빈은 파랑, 폭풍 등 계절적인 요인에 따른 파랑과 바 람의 변화와 수십·수백 년의 기후 및 해수면 변화 등 다양한
범위에서 퇴적물 공급과 운반 사이의 상호 작용에 의해 발달한 다. 그 중에서도 자연적인 해빈의 형성과 변화에 있어 파랑의 영향은 매우 중요한 요인이다.

파랑 에너지와 해안선 변화는 밀접한 관련이 있다. 파랑 에너 지에 따라 형성되는 횡단표사의 유입과 유출의 변화에 의하여 해안선의 변화가 초래된다. 횡단표사는 해안선과 수직방향으로 이동하는 표사를 말하며, 연안역으로 횡단표사 유입과 유출의 관계에 따라 해빈의 침식과 퇴적 특성이 결정되며, 결과적으로 해안선이 전진하고 후퇴하는 등의 반응을 일으킨다. 일반적으 로 파랑 에너지가 낮은 여름철에는 연안으로의 횡단표사가 우 월하여 해안선이 전진하고 파랑 에너지가 큰 겨울철에는 해빈 단의 전면이 깎이며, 외해로의 횡단표사가 발생하여 해안선이 후퇴하는 침식이 발생한다(Kim and Lee, 2015).

파랑 에너지 유입에 의한 해안선의 전진 또는 후퇴 등의 반응 은 Larson and Kraus(1989)에 의하여 이론적으로 처음 제안되었

Received 27 March 2018, revised 21 April 2018, accepted 23 April 2018

Corresponding author Jung-Lyul Lee: +82-31-290-7519, jllee@skku.edu ORCID: https://orcid.org/0000-0001-9410-9725

(C) 2018, The Korean Society of Ocean Engineers

This is an open access article distributed under the terms of the creative commons attribution non-commercial license (http://creativecommons.org/licenses/by-nc/3.0) which permits unrestricted non-commercial use, distribution, and reproduction in any medium, provided the original work is properly cited. 
다. 그 후 Dean(1991)은 양빈 프로젝트에 적용하여 이론적 타당 성을 검증하였고, Kriebel and Dean(1993)과 Miller and Dean (2004)은 폭풍에 의한 현지 해안선 반응에 대한 모델링으로 확장 하였다. 최근에 Yates et al.(2009)은 해빈이 지속적으로 파랑 에 너지에 노출되는 경우 고유한 해안선 위치로 수렴할 것이라는 가정 하에 약 $65 \mathrm{~km}$ 에 달하는 미국 서부 캘리포니아 해변에서 약 5 년간 파랑 에너지, 평균해수면, 해빈측량 그리고 그에 따른 해 안선의 전진 또는 후퇴 양상에 대한 현장관측을 수행하였다.

본 연구에서는 유입 파랑 에너지와 해안선 위치의 변화에 대 한 상관관계를 분석 하는 과정에서 평형 해빈 단면 이론을 적 용한다. 이 이론은 처음 해안 종방향(Cross-shore)으로의 표사이 동과 관련하여 Bruun(1954)와 Bruun(1962)에 의하여 제시되었다. 그 후 평형해빈단면 이론은 초기 직선적 해빈 단면에 대한 침 식 폭 추정(Suh and Dalrymple, 1988), 해빈단면의 응답모형 (Larson and Kraus, 1989)과 양빈 프로젝트에의 적용(Dean, 1991), 사구에서의 해빈단면의 시간적 변화(Plant et al., 1999), 해수면 상승에 의한 해빈단면의 변화(Dubois, 1990), 폭풍해일(Kriebel and Dean, 1993)과 폭풍(Miller and Dean, 2004) 등에 의한 해빈 단면의 시간적 변화 등을 예측하는 실질적인 개념으로 널리 적 용되어 왔다.

해안선 변화 및 평형해빈단면에 관한 우리나라 연구 사례를 살펴보면 해안선 변형 예측에 대한 수치모델 연구(Park et al., 1993), 해수면 상승에 의한 해안선의 잠재적 후퇴거리의 산정 (Son, 1993), 횡단표사에 따른 해안선 변화에 관한 실험적 연구 (Son and Lee, 2000), 강원도 해수욕장의 유영폭 및 해빈단면 축 척계수 조사 분석(Lee and Kim, 2006) 그리고 해빈 종단면 변형 의 수치모의(Cheon and Ahn, 2008) 등에 대한 연구가 수행되었 다. 그러나 선진국에 비하면 아직 미비하며 실제 연안침식을 완 화시키기 위한 해안구조물의 구조설계 및 배치설계 등의 적용 사례에 대한 연구가 현재까지는 부족하다. 그로 인하여 양빈 또 는 우회양빈(Sand bypassing) 등 인위적 해빈조성 공법이나 돌제 또는 잠제 등의 많은 해안구조물이 설치되고 있음에도 현재까 지 성공적인 것으로 평가되는 사업사례가 비교적 드문 만큼 이 에 대한 지속적인 연구가 필요한 실정이다.

본 연구에서는 Dean(1977)의 평형해빈단면의 개념을 이용하 여 유입되는 파랑 에너지에 따라 수렴하는 고유한 해안선 위치 간의 변화관계를 분석한다. 연안표사에 따른 영향은 무시하였 으며, Yates et al.(2009)의 현장관측 결과와 비교하고, 그 개념의 타당성을 또한 검증한다. Yates et al.(2009)은 5년간의 현장 관 측으로부터 유입되는 파랑 에너지에 따른 고유한 해안선 위치 에 대한 관계식을 얻어냈지만 모든 해안에 대하여 이러한 관측 이 수행되지 않고는 그 관계를 명확히 파악하기 어렵기 때문에 본 연구에서는 관측을 수행하지 않고도 해빈 입자 특성으로부 터 그 관계를 얻어내는 방법론을 제시한다.

\section{Yates의 현장관측 실험}

Yates et al.(2009)은 유입되는 파랑 에너지에 따라 해안선의 위치가 어떻게 반응하는 지에 대한 연구를 수행하기 위하여 Fig. 1과 같이 미국 켈리포니아주의 San Diego County에 위치한 길이 약 $65 \mathrm{~km}$ 에 달하는 해안의 4 개 지점(Torrey Pines, Cardiff,

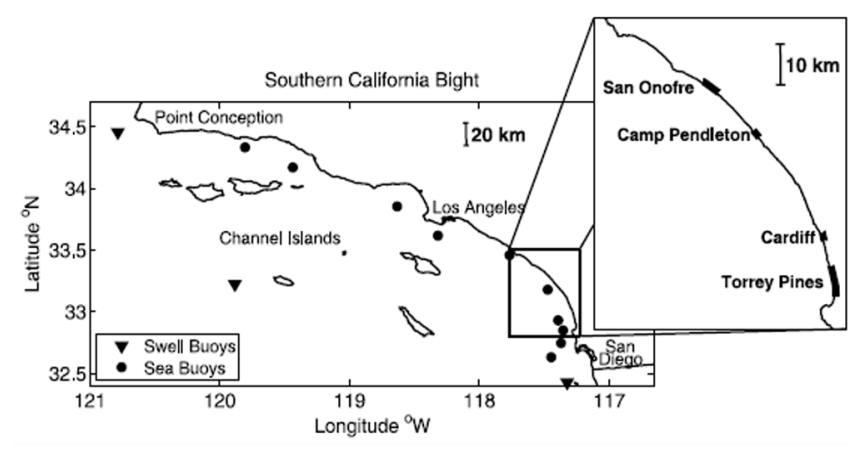

Fig. 1 Study site of Yates et al.(2009)

Table 1 General beach characteristic of survey sites (Yates et al., 2009)

\begin{tabular}{ccccc}
\hline \hline Survey site & $\begin{array}{c}\text { Beach width } \\
{[\mathrm{m}]}\end{array}$ & $\begin{array}{c}\text { Beach } \\
\text { slope }\end{array}$ & $\begin{array}{c}\text { MSL } D_{50} \\
{[\mathrm{~mm}]}\end{array}$ & $\begin{array}{c}D_{50} \text { at } 1 \sim 2 \mathrm{~m} \\
{[\mathrm{~mm}]}\end{array}$ \\
\hline $\begin{array}{c}\text { Torrey pines } \\
\text { Cardiff }\end{array}$ & $20-120$ & $0.01-0.03$ & 0.23 & 0.18 \\
$\begin{array}{c}\text { Camp } \\
\text { pendleton }\end{array}$ & $50-130$ & $0.02-0.04$ & 0.16 & - \\
San onofre & $20-70$ & $0.02-0.04$ & 0.20 & 0.23 \\
\hline
\end{tabular}

Camp Pendleton and San Onofre)에서의 파랑 관측과 해빈 측량 등 주기적인 모니터링을 실시하였다. 조사장소에 대한 일반적 인 특성(해빈 폭, 해빈경사, 모래입경 등)은 Table 1에 제시되었 다. 모든 해변에서의 소조와 대조는 대략 $1.0 \mathrm{~m}$ 및 $2.5 \mathrm{~m}$ 인 것으 로 파악되었다.

Fig. 2는 4개 지점 가운데 Torrey Pines에서의 해빈 측량 결과 와 수심 $10 \mathrm{~m}$ 에서 관측된 파랑 자료, 그리고 해안선의 변동에 대한 상세한 결과를 보여준다. 해빈 측량 자료는 주 또는 월별 관측 자료의 월평균 값으로 제시되었으며 파랑 관측 자료는 스 펙트럼 자료의 시간당 평균값으로 제시되었다. 2007년 4월과 2008년 1월에 실시된 해빈 측량 결과가 각각 제시되었으며 또 한 2007년 10 월 22 일에 관측된 해빈 종단면 기준점 $\mathrm{T} 3$ 에서의 해빈단면 측량 결과가 3 개월 후인 2008년 1 월 22일에 동일 기

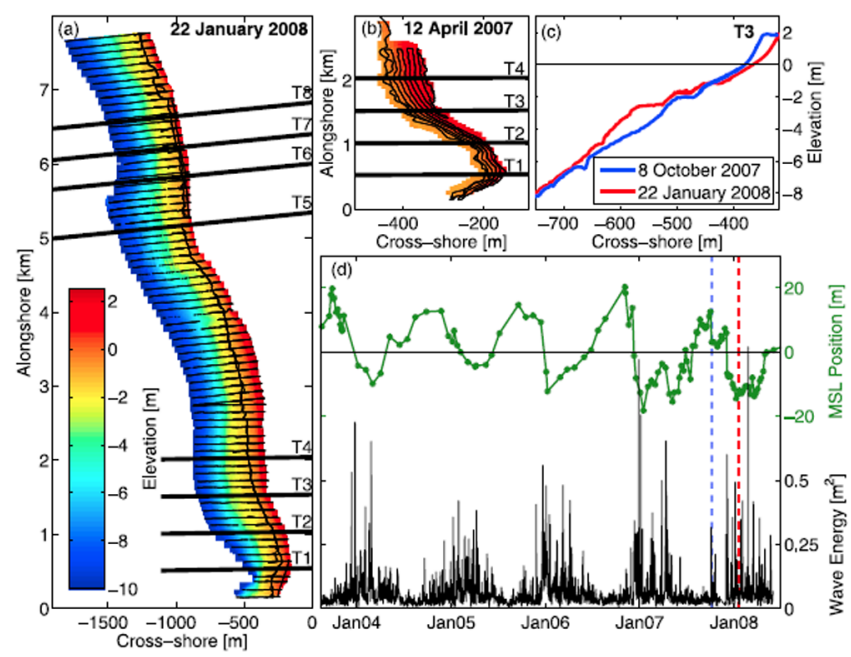

Fig. 2 Survey examples measured in Torrey Pines Beach (Yates et al., 2009) 


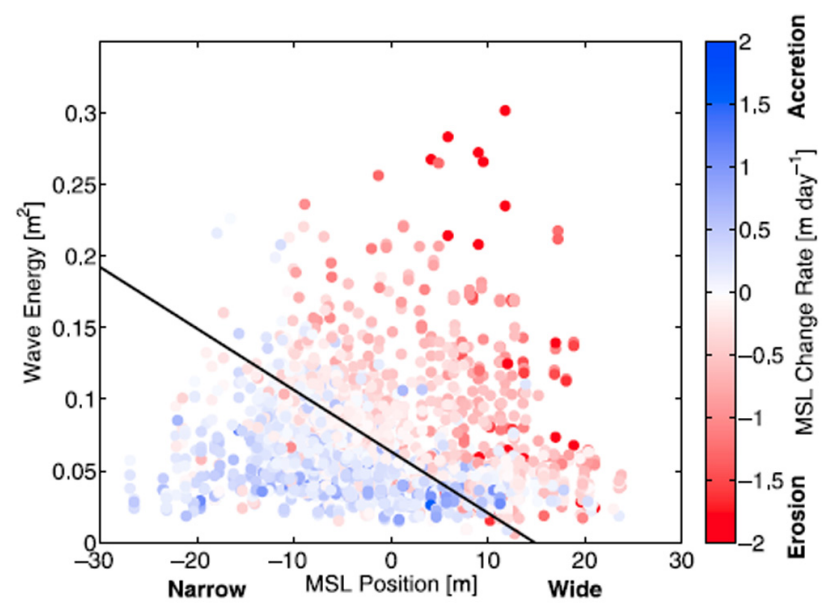

Fig. 3 Mean sea level(MSL) changing rate w.r.t. incident wave energy in Torrey Pines Beach (Yates et al., 2009)

준점에서 관측된 해빈단면 자료와 서로 비교되었다. Torrey Pines의 해안에서 $500 \mathrm{~m}$ 간격으로 $4 \mathrm{~km}$ 에 걸쳐 $\mathrm{T} 1$ 부터 $\mathrm{T} 8$ 까지의 기준점에 대하여 관측이 수행되었다. Fig. 2의 우측 하단에 제시 된 파랑 에너지 관측 자료를 살펴보면 계절적 변동성을 보이고 있으며 이로 인하여 우측 상단에 서로 비교된 해빈단면 결과에 서와 같이 해안선이 후퇴되고 대신 쇄파점 주변에서 연안 사주 가 형성된 모습을 보여주고 있다.

유입 파랑 에너지 $E$ 에 따라서 해안선 위치 MSL(Mean sea level) 에서의 해안선 전진이나 후퇴 경향을 살핀 후 후퇴(Erosion)를 빨 간색, 전진(Accretion)을 파란색으로 표기하면 후퇴와 전진이 발 생하지 않는 경계를 파악할 수 있다. Fig. 3에서 보이는 것과 같이 후퇴와 전진이 발생하지 않는 경계를 검정색 선으로 그릴 수 있 고, 이 선은 유입되는 파랑 에너지에 대하여 수렴되는 해안선 위 치인 것으로 추정할 수 있다.

따라서 이러한 관계식을 얻으면 유입 파랑 에너지에 따라서 해안선이 어떻게 반응할 지를 미리 예측할 수 있으므로 지나치 게 해안선이 후퇴하는 해안에서 고파랑을 제어하는 잠제나 이 안제 등의 해안구조물을 두어 배후 해안으로의 파랑 에너지 유 입을 감소시켜 해안선 후퇴를 제어할 수 있게 된다. 이러한 접 근 방법에서 연안 표사로 인한 영향은 무시되며 연안표사의 영
향이 포함된다면 해안선의 변동 폭은 대부분 더 늘어나는 것으 로 간주될 수 있다.

따라서 Fig. 3으로부터 파랑 에너지 $E$ 가 지속적으로 유입되는 경우 해안선이 궁극적으로 평형해안선의 위치 $S_{e q}$ 로 수렴되는 데 이를 직선이라고 가정하면 다음과 같다.

$$
S_{e q}=\frac{E-b}{a} \text { or } E=a S_{e q}+b
$$

여기서 유입파랑 에너지 $E$ 는 불규칙 파의 경우 아래와 같이 유 의파고 $H_{s}$ 의 함수로 정의된다.

$$
E=\frac{H_{s}^{2}}{16}
$$

그리고 $a$ 와 $b$ 는 $S$ 를 가로축으로 둘 때 각각 직선의 경사와 절 편이 된다. $S=0$ 인 해안선 위치는 연평균 파랑 에너지 $\overline{E_{b}}$ 에 의 하여 수렴되는 해안선의 위치로서 이는 식 (1)에서 $b=\overline{E_{b}}$ 이 되 는 조건을 제공한다.

\section{3. 평형해빈단면에 의한 상관관계 분석}

\subsection{Dean의 평형해빈단면}

Dean(1977)은 Florida Peninsula 근방의 Long Island의 동쪽 끝 에서부터 Texas-Mexico 접경지역까지 미국 502개의 해빈단면에 대한 현지측량을 실시하였으며 각 해빈단면 자료를 취합하고 가장 잘 Fitting하는 보편적 해빈단면 형상을 식 (3)와 같이 유일 한 계수인 해빈축척계수 $A$ 로 표현되는 식을 제안하였다.

$$
h(y)=A y^{2 / 3}
$$

여기서 $h(y)$ 는 수심, $y$ 는 해안선에서부터의 이안거리, $A$ 는 해빈 축척계수(Beach scale factor)로 입경에 의존하는 계수이며 단위는 $m^{1 / 3}$ 이다. 해빈축척계수 $A$ 는 중앙입경과 밀접한 관계가 있는 계 수로서 이를 추정하는 방법은 다양하다. Moore(1982)는 토사의

Table 2 Scale factors according to median grain size (Dean et al., 1977)

\begin{tabular}{cccccccccccc}
\hline \hline \multicolumn{10}{c}{ Summary of Recommended $A$ Values (Unit of $A$ Parameter are $m^{1 / 3}$ ) } \\
\hline$D[\mathrm{~mm}]$ & 0.00 & 0.01 & 0.02 & 0.03 & 0.04 & 0.05 & 0.06 & 0.07 & 0.08 & 0.09 \\
\hline 0.1 & 0.063 & 0.0672 & 0.0714 & 0.0756 & 0.0798 & 0.0840 & 0.0872 & 0.0904 & 0.0936 & 0.0968 \\
0.2 & 0.100 & 0.1030 & 0.1060 & 0.1090 & 0.1120 & 0.1150 & 0.1170 & 0.1190 & 0.1210 & 0.1230 \\
0.3 & 0.125 & 0.1270 & 0.1290 & 0.1310 & 0.1330 & 0.1350 & 0.1370 & 0.1390 & 0.1410 & 0.1430 \\
0.4 & 0.145 & 0.1466 & 0.1482 & 0.1498 & 0.1514 & 0.1530 & 0.1546 & 0.1562 & 0.1578 & 0.1594 \\
0.5 & 0.161 & 0.1622 & 0.1634 & 0.1646 & 0.1658 & 0.1670 & 0.1682 & 0.1694 & 0.1706 & 0.1718 \\
0.6 & 0.173 & 0.1742 & 0.1754 & 0.1766 & 0.1778 & 0.1790 & 0.1802 & 0.1814 & 0.1826 & 0.1838 \\
0.7 & 0.185 & 0.1859 & 0.1868 & 0.1877 & 0.1886 & 0.1895 & 0.1904 & 0.1913 & 0.1922 & 0.1931 \\
0.8 & 0.194 & 0.1948 & 0.1956 & 0.1964 & 0.1972 & 0.1980 & 0.1988 & 0.1966 & 0.2004 & 0.2012 \\
0.9 & 0.202 & 0.2028 & 0.2036 & 0.2044 & 0.2052 & 0.2060 & 0.2068 & 0.2076 & 0.2084 & 0.2092 \\
1.0 & 0.210 & 0.2108 & 0.2116 & 0.2124 & 0.2132 & 0.2140 & 0.2148 & 0.2156 & 0.2164 & 0.2172 \\
\hline
\end{tabular}


유효 크기 사이의 상관관계를 정량화하기 위해 수많은 단면조사 를 했고, 분석에 따르면 가파른 단면과 조개껍질이 대부분인 가 벼운 모래질의 해빈단면에 대해서도 잘 적용되었다. Dean et al.(2001)은 퇴적물의 중앙입경 $D_{50}$ 의 크기를 $0.01 \mathrm{~mm}$ 의 간격으로 $0.1 \mathrm{~mm}$ 로부터 $1.09 \mathrm{~mm}$ 까지의 $A$ 값을 Table 2 에 제시하였다.

\section{2 수렴해안선 위치의 추정}

평형해빈단면식은 쇄파대 내에서 적용되는 식이므로 그 식의 적용 한계는 해안선으로부터 쇄파점(Breaking point)까지이다. 그러므로 파고에 따라서 달라지는 쇄파점이 임의의 해빈 경사 를 따라 발생한다고 가정하면 수렴해안선의 위치를 구할 수 있 다. 쇄파고 $H_{b}$ 에 대하여 쇄파가 시작되는 수심 $h_{b}$ 을 산정하기 위하여 가장 간단하면서도 널리 사용되는 Miche(1944)의 수식 을 적용하였다.

$$
h_{b}=\frac{H_{b}}{\gamma}
$$

여기서 아래첨자 $b$ 는 쇄파점에서의 값을 의미하며 $\gamma$ 는 $0.7 \sim 1.3$ 의 범위를 갖는 값으로 여기서는 평상파에 적용되는 $\gamma=0.78$ 을 사용하였다. 식 (4)를 적용하고 Dean(1977)의 평형해빈단면식을 이용하면 Fig. 4의 $y$ 기준점으로부터 해안선의 변화 폭인 $\triangle y$ 를 아래와 같이 산출할 수 있다.

$$
\triangle y=m h_{b}-\left(\frac{h_{b}}{A}\right)^{\frac{3}{2}}
$$

여기서 $m$ 은 Fig. 4 에 도시된 바와 같이 평형해빈단면식이 유효 한 외해 한계점 즉, 쇄파 시작점을 연결한 선의 경사로서 직선 인 것으로 가정되었다.

Fig. 4에서 수렴해안선 위치의 변화를 나타내는 $S$ 가 파랑 에 너지가 0 인 경우에 수렴되는 해안선 위치가 기준이 되는 것이 아니라 가장 빈도가 높은 파랑 에너지인 평균 파랑 에너지에 의하여 수렴되는 해안선의 위치인 $O$ 점이 기준이 된다면 수렴 해안선 위치 $S_{e q}$ 에 대한 식은 아래 식과 같이 주어진다.

$$
S_{e q}=\left[A^{-3 / 2}\left(\bar{h}_{b}^{3 / 2}-h_{b}^{3 / 2}\right)\right]-m\left(\bar{h}_{b}-h_{b}\right)
$$

Fig. 4에서 $S_{o}$ 는 파랑 에너지가 거의 유입되지 않는 상태의

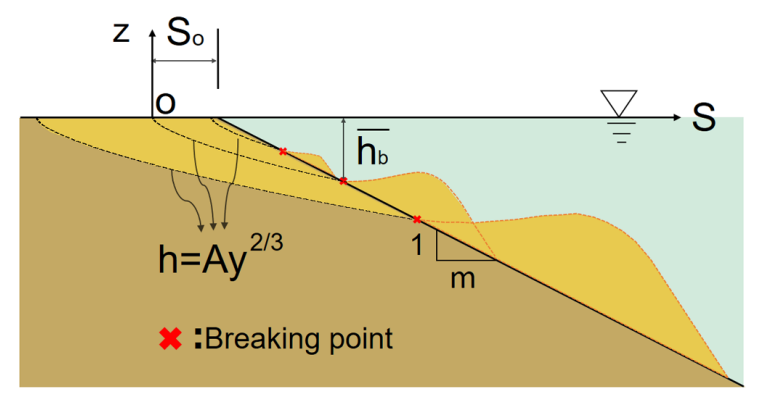

Fig. 4 Definition sketch of shoreline response concept using an equilibrium beach profile
평형해안선 위치로서 천수 효과를 무시하면 식 (1)에서 $-b / a$ 에 해당되는 값이며 식 (6)에서 $h_{b}=0$ 으로 두면 얻을 수 있는 값이 다. 즉,

$$
m \bar{h}_{b}-\left(\frac{\overline{h_{b}}}{A}\right)^{-3 / 2}=\frac{b}{a}=\frac{\overline{E_{b}}}{a}
$$

식 (1)과 유사한 형태로 식 (7)을 식 (6)에 대입하면 다음 결과 를 얻는다.

$$
S_{e q}=\left[\frac{16}{\gamma^{2}}\left(\frac{m}{h_{b}}-\frac{1}{A^{3 / 2} h_{b}^{1 / 2}}\right)\right]\left(E_{b}-\overline{E_{b}}\right)
$$

식 (8)의 대괄호 안의 값은 $-1 / a$ 에 해당되며 관측 결과에 따 르면 이 결과는 유입 에너지에 관계없이 거의 일정한 값으로 추정되었다. 따라서 다음과 같이 식 (1)과 유사한 식으로 변환 될 수 있다.

$$
S_{e q}=\frac{E_{b}-\overline{E_{b}}}{a}
$$

Fig. 3과 같이 식 (8)에서 대괄호 안의 값이 유입 에너지에 관 계없이 거의 일정한 값이 된다면 해빈경사 $m$ 이 Scale factor $A$ 와 어떤 관계가 있는 지를 또한 판단할 수 있다. 다소 까다로운 수학적 검토 후 해빈 경사와 축척 계수간의 관계가 아래와 같 은 경우 수심의 영향을 덜 받고 거의 일정한 값을 제공하는 것 으로 판단되었다.

$$
m=\frac{f}{A^{3 / 2}}
$$

식 (10)을 식 (8)에 적용하면 $a$ 에 대하여 다음 결과를 얻는다.

$$
a \simeq \frac{\gamma^{2} A^{3 / 2}}{16}\left(\frac{h_{b}}{f-\sqrt{h_{b}}}\right)
$$

여기서 $f$ 는 해변 조건과 관계없이 거의 일정한 상수인 것으로 간주될 수 있다. 식 (11)은 또한 해빈경사 $m$ 의 함수로도 아래와 같이 주어진다.

$$
a \simeq \frac{\gamma^{2} f}{16 m}\left(\frac{h_{b}}{f-\sqrt{h_{b}}}\right)
$$

따라서 Table 1에 제시된 해빈 경사와 입경 자료를 이용하여 식 (9)로부터 $f$ 를 추산하고 평균을 구하면 약 1.17 의 평균값을 갖는다. 계산 과정은 Table 2에 제시되었다. $f$ 의 값이 0.86 부터 1.80 까지 큰 변화를 보이고 있다. Table 1 에서와 같이 해빈 경사 가 대략적으로 제시되었으며 해빈 경사와 중앙 입경 자료를 서 로 비교하였을 때 해빈 경사가 급할수록 입경이 커지는 보편적 인 경향이 만족되지 못하고 있다. 따라서 유입 파고에 따라 부 
Table 3 Results of parameter $f$ at survey sites

\begin{tabular}{ccccccc}
\hline \hline Survey Site & $\begin{array}{c}\text { Beach Slope } \\
1 / m\end{array}$ & $\begin{array}{c}\text { Mean Slope } \\
1: m\end{array}$ & $\begin{array}{c}\text { MSL } D_{50} \\
{[\mathrm{~mm}]}\end{array}$ & $\begin{array}{c}D_{50} \text { at } 1 \sim 2 \mathrm{~m} \\
{[\mathrm{~mm}]}\end{array}$ & $\begin{array}{c}\text { Scale Factor } \\
A\left[\mathrm{~m}^{1 / 3}\right]\end{array}$ & $\begin{array}{c}\text { Parameter } \\
f\left[\mathrm{~m}^{1 / 2}\right]\end{array}$ \\
\hline Torrey pines & $0.01-0.03$ & 50.0 & 0.23 & 0.18 & 0.1090 & 1.80 \\
Cardiff & $0.02-0.04$ & 33.3 & 0.16 & - & 0.0872 & 0.86 \\
Camp pendleton & $0.02-0.04$ & 33.3 & 0.20 & 0.23 & 0.1000 & 1.05 \\
San onofre & $0.03-0.05$ & 25.0 & 0.26 & 0.35 & 0.1170 & 1.00 \\
\hline
\end{tabular}

Table 4 Results of $D_{50}$ estimated from the beach slopes

\begin{tabular}{ccccccc}
\hline \hline & \multicolumn{3}{c}{ Observed } & \multicolumn{3}{c}{ Estimated } \\
\cline { 2 - 8 } Survey site & Mean slope & MSL $D_{50}$ & $D_{50}$ at $1 \sim 2 \mathrm{~m}$ & Parameter & Scale factor & Grain size $D_{50}$ \\
& $1 / m$ & {$[\mathrm{~mm}]$} & {$[\mathrm{mm}]$} & $f\left[\mathrm{~m}^{1 / 2}\right]$ & $A\left[\mathrm{~m}^{1 / 3}\right]$ & {$[\mathrm{mm}]$} \\
Torrey pines & 50.0 & 0.23 & 0.18 & & 0.0823 & $0.14 \sim 0.15$ \\
Cardiff & 33.3 & 0.16 & - & mean & 0.1079 & $0.22 \sim 0.23$ \\
Camp pendleton & 33.3 & 0.20 & 0.23 & 1.18 & 0.1079 & $0.22 \sim 0.23$ \\
San onofre & 25.0 & 0.26 & 0.35 & & 0.1306 & $0.32 \sim 0.33$ \\
\hline
\end{tabular}

유사 이동이 심한 점을 고려하면 MSL에서의 모래 입경의 대표 성이 해빈 경사에 비하여 부족할 수도 있다고 판단된다. 식 (9) 에 각 해빈의 평균 해빈경사를 적용하고 $f$ 의 평균값인 1.18 을 취하면 각 해빈의 축척계수인 $A$ 를 구할 수 있다 그리고 Table 2 로부터 구해진 $A$ 값에 해당하는 중앙 입경 $D_{50}$ 를 구한 결과를 제시하면 Table 4 와 같다. 파랑 조건에 둔감하고 전반적인 해빈 의 특성을 잘 반영하는 해빈 경사가 해빈 특성의 대표성을 갖 는다고 보았을 때 이렇게 추산한 중앙 입경은 장기간 평균된 입경 정보를 제공할 것으로 판단된다.

Dean(1977)의 평형해빈단면 이론식으로부터 얻은 식 (11) 또 는 식 (12)는 Yates et al.(2009)에서 수행한 장시간의 관측이 없 이도 기존 모니터링 자료인 중앙 입경이나 해빈 경사로부터 직 접 쇄파되는 점에서의 파랑 에너지를 안다면 해안선이 어떻게 수렴하게 되는 지를 파악 할 수 있는 간편한 수단이 된다. Table 5는 Yates et al.(2009)의 관측 자료로부터 얻은 결과로서 식 (1) 의 $a$ 와 식 (11)의 근사 해인 $a$ 결과를 서로 비교한 것이다. 식 (11)에서 $a$ 는 수심에 따라 약간의 변화를 보이는 데 Table 5의 결과는 수심 $3 \mathrm{~m}$ 에 대한 결과를 제시한 것이다.

Torrey Pines 해변과 Camlp Pendleton 해변의 경우 해빈경사 자료로부터 얻은 결과가 더 근접한 결과를 제시하고 있으나 Cardiff 해변의 경우는 MSL에서 관측된 중앙입경 자료로부터 얻은 결과가 더 근접한 결과를 보이고 있다. 여기서 유념할 것
은 관측된 $a$ 값은 수심 $10 \mathrm{~m}$ 에서 관측된 파랑 에너지로부터 얻어 진 결과이며 계산된 $a$ 는 쇄파점에서의 파랑 에너지로부터 추출 한 것이다. 참고로 수심 $10 \mathrm{~m}$ 에서 주기 6초인 파랑의 파랑 에너 지가 $0.2 \mathrm{~m}^{2}$ 인 경우 $10 \mathrm{~m}$ 지점으로부터 쇄파점까지의 천수계수는 약 1.13 이 된다.

식 (6)을 이용하면 유입되는 파랑 에너지별로 해안선이 어떻게 반응하는 지를 살펴볼 수 있다. 식 (6)에 주어진 쇄파점에서의 파 고를 수심 $10 \mathrm{~m}$ 에서의 파고로의 변환을 위하여 조석의 영향은 무 시하고 천수 효과를 반영하였다. 파향 자료가 없는 관계로 굴절 은 무시되었다. Fig. 5는 Torrey Pines 해변에 대한 결과로서 Fig. 3 과 같은 조건에 대하여 적용한 식 (8)의 결과이다. 해빈경사 $\mathrm{m}$ 은 평균값인 50 으로 간주하였으나 Table 5 에 주어진 바와 같이 축척 계수는 2 가지 값에 대하여 적용되었다. 즉, $\mathrm{MSL}$ 에서 채취한 모 래의 중앙입경을 사용하여 얻은 $A=0.109 \mathrm{~m}^{1 / 3}$ 의 경우와 $m=50$ 으 로부터 식 (10)의 관계를 이용한 얻은 $A=0.0818 \mathrm{~m}^{1 / 3}$ 의 경우이다. 후자의 경우 관측 결과와 유사한 결과를 보이고 있으나 전자의 경우는 해빈경사에 비하여 중앙입경이 크게 관측되어서 Table 5 의 Observed $a$ 에 제시된 \pm 2.0 의 오차 범위 내에 놓이지 못한 것 으로 판단된다. 수심 $1 \sim 2 \mathrm{~m}$ 에서 관측된 중앙입경은 MSL에 비하 여 작은 입경인 $0.18 \mathrm{~mm}$ 인 것으로 관측되었으나 MSL에서 대체로 큰 입경을 보이는 경향이 있다는 점을 고려하면 아직도 본 연구 성과를 만족시키지 못하는 관측 결과인 것으로 판단된다.

Table 5 Comparison of correlation curve slope $a$ for survey sites

\begin{tabular}{|c|c|c|c|c|}
\hline \multirow{2}{*}{ Survey site } & MSL $D_{50}[\mathrm{~mm}]$ & \multirow{2}{*}{$\begin{array}{l}\text { Scale factor A } \\
\qquad\left[\mathrm{m}^{1 / 3}\right]\end{array}$} & \multirow{2}{*}{$\begin{array}{l}\text { Observed } a \\
{\left[\times 10^{-3} \mathrm{~m}^{2} / \mathrm{m}\right]}\end{array}$} & \multirow{2}{*}{$\begin{array}{c}\text { Calculated } a \\
{\left[\times 10^{-3} \mathrm{~m}^{2} / \mathrm{m}\right] \text { at } \mathrm{h}_{\mathrm{b}}=3 \mathrm{~m}}\end{array}$} \\
\hline & Beach slope $m$ & & & \\
\hline \multirow{2}{*}{ Torrey pines } & 0.23 & 0.1090 & \multirow{2}{*}{$-4.5 \pm 2.0$} & -7.4 \\
\hline & 50.0 & 0.0818 & & -4.9 \\
\hline \multirow{2}{*}{ Cardiff } & 0.16 & 0.0872 & \multirow{2}{*}{$-4.2 \pm 1.0$} & -5.3 \\
\hline & 33.3 & 0.1073 & & -7.3 \\
\hline \multirow{2}{*}{ Camp pendleton } & 0.20 & 0.1000 & \multirow{2}{*}{$-8.5 \pm 1.7$} & -6.5 \\
\hline & 33.3 & 0.1073 & & -7.3 \\
\hline
\end{tabular}




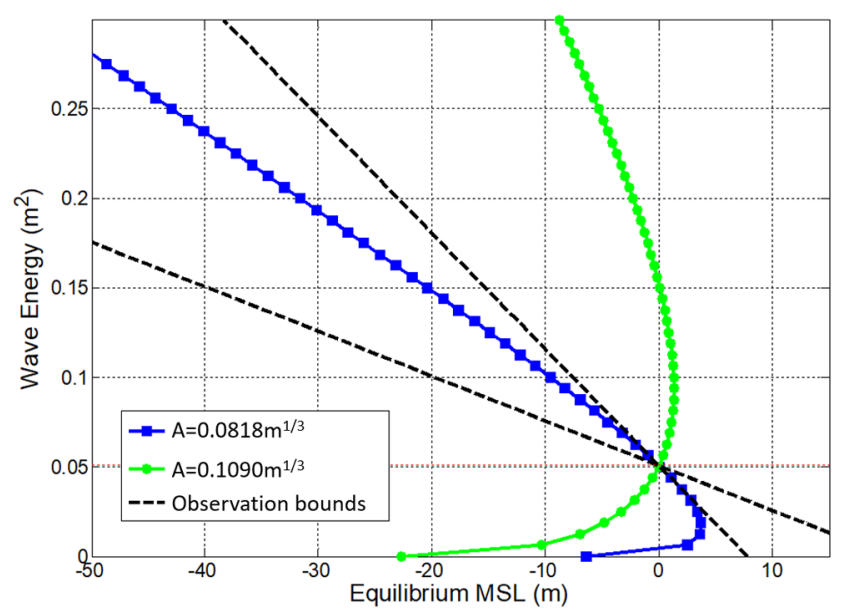

Fig. 5 Comparison between observed and predicted MSL changing rates for Torrey Pines beach $\left(A\right.$ unit $\left.: \mathrm{m}^{1 / 3}\right)$

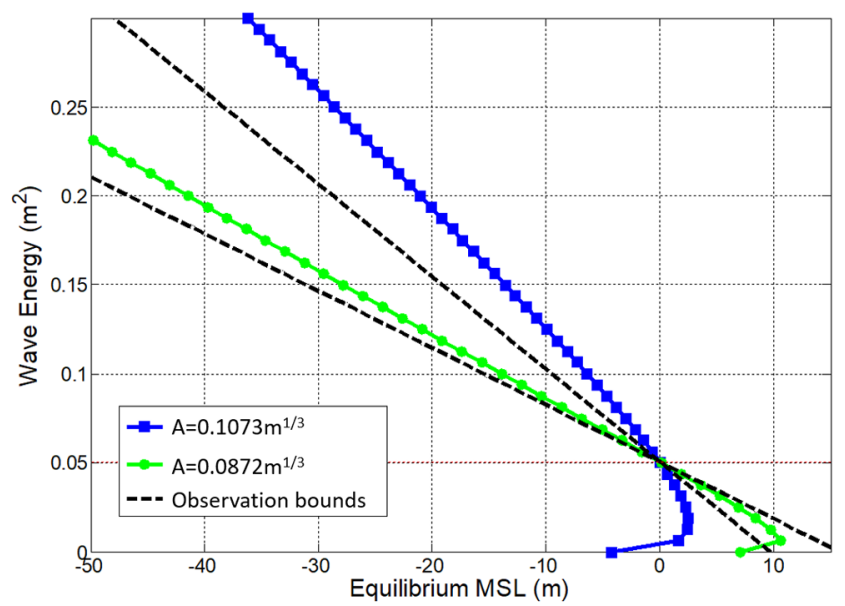

Fig. 6 Comparison between observed and predicted MSL changing rates for Cardiff beach $\left(A\right.$ unit $\left.: \mathrm{m}^{1 / 3}\right)$

Cardiff 해변에 대해서는 해빈 경사 $m$ 을 평균 해빈 경사 값 인 33.3으로 적용하고 얻은 결과가 Fig. 6에 도시되었다. Torrey Pines 해변과 마찬가지로 축척 계수는 2 가지 값에 대하여 적용 되었다. 즉, MSL에서 채취한 모래의 중앙입경을 사용하여 얻은 $A=0.0872 \mathrm{~m}^{1 / 3}$ 의 경우와 $m=33.3$ 으로부터 식 (10)의 관계를 이용 하여 얻은 $A=0.1073 \mathrm{~m}^{1 / 3}$ 의 두가지 경우이다. Torrey Pines 해변 과 달리 전자의 경우 관측 결과와 비교적 유사한 결과를 보이 고 있으나 후자의 경우는 해빈경사에 비하여 중앙입경이 작게 관측되어서 Table 5 의 Observed $a$ 에 제시된 \pm 1.0 의 오차 범위 내로 들어오지 못했다.

Camp Pendleton 해변에 대해서도 Cardiff 해변과 같이 해빈 경 사 $m$ 을 33.3으로 적용하였다. Fig. 7에 그 결과가 도시되었다. $\mathrm{MSL}$ 에서 채취한 모래의 중앙입경을 사용하여 얻은 $A=0.10 \mathrm{~m}^{1 / 3}$ 의 경우와 $m=33.3$ 으로부터 얻은 $A=0.1073 \mathrm{~m}^{1 / 3}$ 의 경우이다. Torrey Pines 해변과 마찬가지로 후자의 경우 관측 결과와 좀 더 유사한 결과를 보이고 있으며 전자의 경우는 해빈경사에 비하여 중앙입 경이 작게 관측되어서 Table 5 의 Observed $a$ 에 제시된 \pm 1.7 의 오차 범위 내로 들어오지 못했다. 그러나 수심 $1 \sim 2 \mathrm{~m}$ 에서 관측된

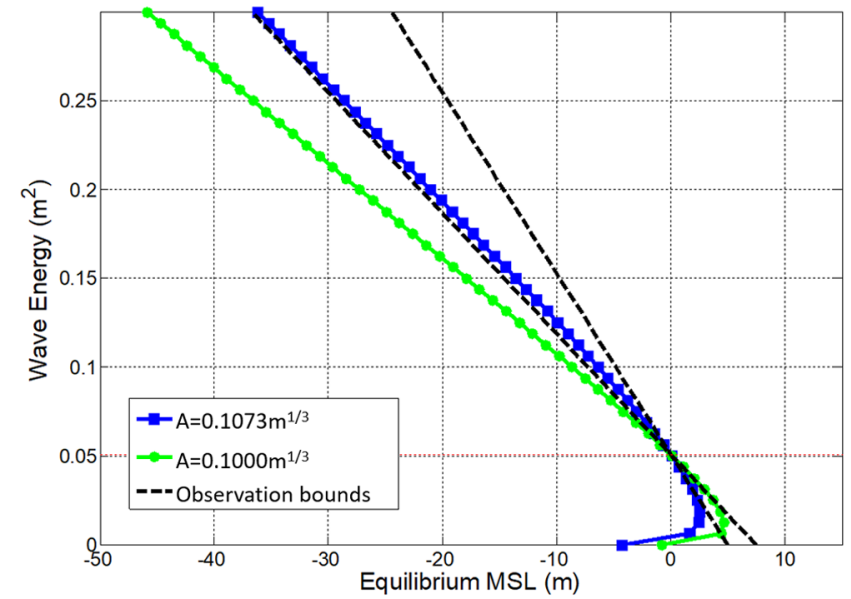

Fig. 7 Comparison between observed and predicted MSL changing rates for Camp Pendleton beach ( $A$ unit $: \mathrm{m}^{1 / 3}$ )

중앙입경이 MSL에 비하여 훨씬 큰 것을 감안하면 본 연구 성과 를 충분히 만족시킬 수 있는 해변 조건을 갖춘 것으로 판단된다.

이상의 결과를 종합하면 Dean(1977)의 평형해빈단면식을 이 용하여 유입파랑 에너지 또는 유입파고로부터 해안선이 반응하 는 것을 손쉽게 예측할 수 있으리라 판단된다. 축척계수 또는 중앙입경이 커질수록 해안선의 반응은 둔화되며 해빈 단면 특 성을 결정하는 축척계수와 해빈경사 간의 밀접한 상관관계가 존재할 것으로 판단된다. 식 (6)을 적용하는 경우 식 (11) 또는 식 (12)로부터 직접 해안선의 상관계수 $a$ 를 얻은 결과와 비교하 여 에너지와 해안선의 상관계수를 통하여 예측한 결과와 유사 한 경향을 보이고 있다. 그러나 식 (6)은 평균파고보다 작은 파 랑이 유입하는 경우 해안선이 오히려 음수의 $S_{e q}$ 를 보이며 침식 되는 결과를 보이고 있어 이에 대하여 향후 현장 자료와의 비 교를 통하여 확인이 필요하다. 당장 이러한 문제점은 식 (6)을 직접 이용하는 것이 아니라 식 (8)을 적용하면 해결될 수 있다. 그러나 향후 현장 관측을 통하여 저파랑이 유입되는 경우는 물 론 전반적으로 본 논문에서 제시한 개념의 타당성이 확인될 필 요성은 있다.

\section{4. 결 론}

본 연구에서는 미국 캘리포니아 해변에서 수행된 Yates et al.(2009)의 현장관측 실험 결과로서 얻은 유입파랑 에너지와 수 렴해안선위치와의 상관관계 계수들의 편리한 추정을 위하여 Dean(1991)의 평형해빈단면의 축척계수 $A$ 와 평균해빈단면 경사 $m$ 으로부터 유입 파랑 에너지와 수렴 해안선간의 간단한 관계 식을 제시하였다. 이 식의 결과는 Yates et al.(2009)의 3지점에 서 제시된 상관관계 계수와 비교되었으며 대체로 만족할만한 결과를 얻었다. 또한 Yates et al.(2009)의 실험 결과로부터 평형 해빈단면의 축척계수 $A$ 와 평균해빈단면 경사 $m$ 간의 관계를 분 석하였으며 이 결과를 이용하여 유입파랑 에너지에 민감한 중 앙입경보다 둔감한 해빈단면경사를 이용하면 Yates의 결과와 좀 더 안정적이면서도 유사한 결과를 낳는 것으로 분석되었다. 따라서 Yates et al.(2009)과 같은 현장관측 실험을 수행하지 
않아도 횡단표사로부터 발생하는 해안선의 전진 및 후퇴 경향 을 유입하는 파랑 에너지의 함수로 쉽게 추정할 수 있는 방법 인 것으로 평가되며, 특히 고파랑 내습으로 인한 해안침식을 완 화하기 위한 대표적으로 해안구조물인 잠제 및 이안제의 침식 저감 기능 설계에도 중요한 정보를 제공할 수 있는 것으로 판 단된다. 향후 국내의 해안선 모니터링 자료와 해빈 단면 모니터 링 자료를 적용하여 좀 더 정밀한 비교 및 검증이 필요할 것으 로 사료된다.

$$
\text { 후기 }
$$

본 연구는 해양수산부의 “연안침식 저감기술 개발” 성과 중 일부이며, (주대영엔지니어링의 “침식저감 해안구조물의 배치설 계 연구”의 연구비 지원과 공동 논의 결과로 구체적 성과를 이 루었음을 밝히며 연구비 지원에 감사드립니다.

\section{References}

Bruun, P., 1954. Coastal Erosion and Development of Beach Profiles. Technical Memorandum No. 44, US Army Corps of Engineers, Washington, D.C.

Bruun, P., 1962. Sea-Level Rise as a Cause of Shore Erosion. Journal of the Waterways and Harbors Division, 88(1), 117-132.

Cheon, S.H., Ahn, K.M., 2008. Numerical Simulation of Beach Profile Changes. Journal of Korean Society of Coastal and Ocean Engineers, 20(1), 101-109.

Dean, R.G., 1977. Equilibrium Beach Profiles: U.S. Atlantic and Gulf Coasts. Technical Report No. 12, Department of Civil Engineering, University of Delaware.

Dean, R.G., 1991. Equilibrium Beach Profiles: Characteristics and Applications. Jounal of Coastal Research, 7(1), 53-84.

Dean, R.G., Walton, T.L., Kriebel, D.L., 2001. Cross-shore sediment transport. Coastal Engineering Manual, U.S. Army Coastal and Hydraulics Laboratory.

Dubois, R.N., 1990. Barrier-beach erosion and rising sea level. Geology, 18(11), 1150-1152.

Kim, D.S,. Lee, K.L., 2015. Seasonal Changes of Shorelines and Beaches on East Sea Coast, South Korea. Journal of the Korean
Geographical Society, 50(2), 147-164.

Kriebel, D.L., Dean, R.G., 1993. Convolution Method for Time-Dependent Beach Profile Response. Journal of Waterway, Port, Coastal Ocean Engineering, 119(2), 204-226.

Larson, M., Kraus, N.C., 1989. SBEACH: Numerical Model for Simulating Storm-Induced Beach Change - Report 1 Empirical Foundation and Model Development. Technical Report, CERC-89-9, US Army Corps of Engineering.

Lee, J.L., Kim, I.H., 2006. A Survey and Analysis of Swim Zone Width and Beach Scale Factor for Gangwon Beaches. Journal of Korean Society of Coastal and Ocean Engineers, 18(3), 241-250.

Miche, R., 1944. Mouvement Ondulatoires De La Mer en Profondeur Constante ou Decroissante. Annales de Ponts et Chaussees.

Miller, J.K., Dean, R.G., 2004. A Simple New Shoreline Change Model. Coastal Engineering, 51(7), 531-556.

Moor, B.D., 1982. Beach profile evolution in response to changes in water level and wave height. MCE Thesis, Department of Civil Engineering, University of Delaware, 164.

Park, J.C., Han, K.M., Kim, J.J., 1993. A Study on the Numerical Model for Predicting Shoreline Changes. Journal of Ocean Engineering and Technology, 7(1), 156-161.

Plant, N.G., Holman, R.A., Freilich, M.H., 1999. A Simple Model for Interannul Sandbar Behavior. Journal of Geophys. Res., 104(C7), 15755-15776.

Son, C.B., 1993. Prediction of Potential Shoreline Retreat by Sea Level Rise. Journal of Korean Society of Coastal and Ocean Engineers, 11(1), 34-40.

Son, C.B., Lee, S.K., 2000. An Experimental Study on the Shoreline Change during Beach Process. Journal of Ocean Engineering and Technology, 14(3), 55-60.

Suh, K.D., Dalrymple, R.A., 1988. Expression for Shoreline Advancement of Initially Plane Beach. Journal of Waterway, Port, Coastal and Ocean Engineering, 114(6), 770-777.

Yates, M.L., Guza, R.T., O'Reilly, W.C., 2009. Equilibrium Shoreline Response: Obersrvations and Modeling. Journal of Geophysical Research, 114(C9), C09014. 